\title{
Correction to: The EU Top Court Rules that Married Same-Sex Couples Can Move Freely Between EU Member States as "Spouses": Case C-673/16, Relu Adrian Coman, Robert Clabourn Hamilton, Asociația Accept v Inspectoratul General pentru Imigrări, Ministerul Afacerilor Interne
}

\author{
Alina Tryfonidou ${ }^{1}$ (D) \\ Published online: 24 June 2019 \\ (C) The Author(s) 2019

\section{Correction to: Feminist Legal Studies https://doi.org/10.1007/s10691-019-09397-z}

The article "The EU Top Court Rules that Married Same-Sex Couples Can Move Freely Between EU Member States as "Spouses": Case C-673/16, Relu Adrian Coman, Robert Clabourn Hamilton, Asociaţia Accept v Inspectoratul General pentru Imigrări, Ministerul Afacerilor Interne", written by "Alina Tryfonidou" was originally published electronically on the publisher's internet portal (currently SpringerLink) on 23 April 2019 without open access.

With the author(s)' decision to opt for Open Choice the copyright of the article changed on 24 June 2019 to (C) The Author(s) 2019 and the article is forthwith distributed under the terms of the Creative Commons Attribution 4.0 International License (http://creativecommons.org/licenses/by/4.0/), which permits use, duplication, adaptation, distribution and reproduction in any medium or format, as long as you give appropriate credit to the original author(s) and the source, provide a link to the Creative Commons license and indicate if changes were made.

The original article has been corrected.

Open Access This article is distributed under the terms of the Creative Commons Attribution 4.0 International License (http://creativecommons.org/licenses/by/4.0/), which permits unrestricted use, distribution, and reproduction in any medium, provided you give appropriate credit to the original author(s) and the source, provide a link to the Creative Commons license, and indicate if changes were made.

The original article can be found online at https://doi.org/10.1007/s10691-019-09397-z.

Alina Tryfonidou

a.tryfonidou@reading.ac.uk

1 Foxhill House, School of Law, University of Reading, Whiteknights Road, Earley,

Reading RG6 7BA, UK 
Publisher's Note Springer Nature remains neutral with regard to jurisdictional claims in published maps and institutional affiliations. 